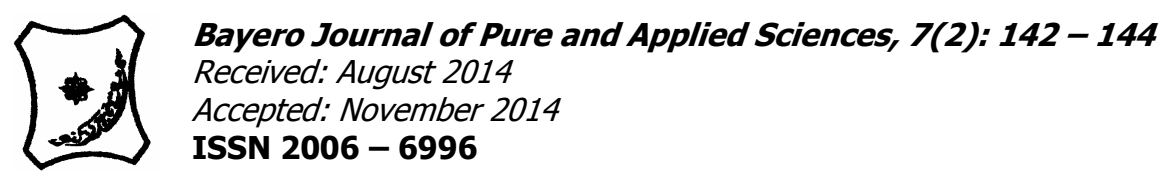

\title{
EVALUATION OF DIFFERENT FEEDING FREQUENCIES ON GROWTH PERFORMANCE AND FEED UTILIZATION OF Clarias gariepinus (Burchell, 1822). FINGERLINGS
}

\author{
${ }^{1}$ Haruna, M. A., ${ }^{2}$ Muhd, I. U., ${ }^{3}$ Ahmad, M. K. and ${ }^{4}$ Umar, R. \\ ${ }^{1}$ Department of Fisheries, Faculty of Agriculture, Federal University Dutse, P.M.B.7156, Jigawa State, \\ Nigeria. \\ ${ }^{2}$ Department of Fisheries, Binyaminu Usman College of Agriculture, Hadejia, Jigawa State, Nigeria. \\ ${ }^{3}$ Department of Biological Sciences, Bayero University Kano, Nigeria. \\ ${ }^{4}$ National Agricultural Extention and Research Liaison Services, Ahmadu Bello University, Zaria, Nigeria. \\ *Correspondence author; auwal3@yahoo.com
}

\begin{abstract}
The experiment was conducted to assess the growth performance and feed utilization of Clarias gariepinus under the feeding frequencies of T1 (twice/day), T2 (thrice/day), and T3 (four times/day) at 3\% BWD per day over a period of 56 days. A total of 180 fingerlings with average weight of $2.39 \pm 0.19 \mathrm{~g}$ and average length of $5.02 \pm 1.04 \mathrm{~cm}$ were stocked at 15 fish per plastic container of 35 litres capacity. The highest weight gain recorded at the end of the experiment was $7.39 \pm 0.19 \mathrm{~g}$ in (T3) and the lowest was $5.35 \pm 0.31 \mathrm{~g}$ in (T1). The highest specific growth rate (SGR\%) value of $1.19 \pm 0.02$ was recorded in (T3) and the lowest $1.01 \pm 0.03$ was recorded in (T1). $T 3$ recorded the highest FCR value of $1.88 \pm 1.37$, while the lowest value of $8.34 \pm 2.12$ was obtained in (T1). Therefore, Treatment 3 yielded the best performance in terms of WG, SGR, and FCR and can be recommended for enhanced growth performance and optimum feed utilization.

Keywords; Fingerlings, feeding, frequency, growth, performance, utilization.

INTRODUCTION

One problem facing fish culturists is the need to obtain a balance between rapid fish growth and optimum use of the supplied feed (Gokcek et al, 2008). There is also the need to establish the effect of

especially protein will positively influence its growth rate (Sagbesan and Ugwumba, 2008). This study was therefore aimed at determining the best feeding frequency and feed utilization of Clarias gariepinus fingerlings.
\end{abstract} number of feeding frequency on feed management, nutrient utilization and growth rate of fish. Since the feed cost accounts approximately $40-60 \%$ of the operating cost in intensive culture systems (Agung, 2004), the economic viability of the culture operation depends on the feed and feeding frequency. It means that nutritionally well-balanced diets and their adequate feeding are the main requirements for successful culture operation. Feeding frequency is one important consideration as it can affect growth, survival and fillet composition as well as water quality. Feeding also at the optimum frequency can result in tremendous savings in feed cost (Davies et al., 2006).

The amount of the daily feed intake, frequency and timing of the feedings and presentation of the predetermined ration are the key factors of feed management strategies, influencing the growth and feed conversion (Goddard, 1995; and Jobling, 1995). Optimal feeding frequency may vary depending on species, age, size, environmental factors, husbandry and feed quality (Goddard, 1995). Two or three feeding a day have been found to be sufficient for maximum growth of a number of different fish species (Ruohonen et al., 1998).

Efficient production and growth of fish depends on feeding the best possible diets at levels not exceeding the dietary needs (Charles et al., 1984). The ability of an organism to utilize nutrients

\section{MATERIALS AND METHODS Study Location}

The experiment was carried out at the hatchery complex of Bagauda Fisheries Research Institute, Kano, Nigeria. The study area lies between latitudes $11^{\circ} 20^{\prime}$ and $11^{\circ} 45^{\prime}$ North and longitudes $8^{\circ}$ $15^{\prime}$ and $8^{\circ} 30^{\prime}$ East.

Experimental Fish

Clarias gariepinus fingerlings of $2.39 \pm 0.19 \mathrm{~g}$ average weight and $5.02 \pm 1.04 \mathrm{~cm}$ average length were obtained from A4 Global Fisheries, a private consultancy outfit, behind school of nursing, Karkasara road, Kano and were acclimatized for a period of one week (7days) in 35L plastic containers and were fed a maintenance diet of $(1.5 \mathrm{~mm})$ size commercial feed (Coppens) containing $45 \%$ crude protein. All fishes were weighed individually at the beginning and end of the experiment using Ohaus electric balance of $310 \mathrm{~g}$ capacity. A total of 180 fishes were used for the experiment.

Tank Preparation and Water Supply

Twelve plastic containers of $35 \mathrm{~L}$ capacity and circular in shape were used for the experiment. Uniform water level was maintained to compensate for water loss due to evaporation and the water was obtained from the University bore-hole. 


\section{Experimental Design \& Layout}

Three Treatments (T1, T2, and T3) replicated thrice were used for the experiment. The experiment was laid out in a Completely Randomised Block Design (RCBD) with fifteen (15) fishes stocked in each plastic of $35 \mathrm{I}$ capacity. The experiment was conducted over a period of eight weeks (56 days).

\section{Feeding Rate \& Frequency}

Three Treatments at different feeding frequencies of $\mathrm{T} 1$ (twice/day; 9.00am and $12.00 \mathrm{pm}$ ), T2 (thrice/day; 9.00am, 12.00pm and 3.00pm) and T3 (four times/day; 9.00am, $12.00 \mathrm{pm}, 3.00 \mathrm{pm}$ and $6.00 \mathrm{pm}$ ) were allocated. Experimental diet (Coppens, $1.5 \mathrm{~mm}$ ) with $45 \%$ crude protein, was used at $3 \%$ body weight per day (BWD) for the study and the quantity of feed was adjusted weekly according to mean weight gain.

\section{Length-Weight Measurement}

Length measurement was carried out to the nearest centimeters using a measuring board graduated in centimeters. Total length ( $T L$ ) was measured from the anterior most extremity of the fish to the end of the caudal fin. The total weight was measured in grams using Ohaus electric balance of $310 \mathrm{~g}$ capacity.

\section{Water Quality Monitoring}

Water quality parameters of (temperature, DO, and $\mathrm{p}^{\mathrm{H}}$ ) were monitored weekly. Temperature was measured with mercury-in-glass thermometer calibrated in degree centigrade $\left({ }^{\circ} \mathrm{C}\right)$, dissolved oxygen (DO) was determined using Winkler's method and $\mathrm{p}^{\mathrm{H}}$ was determined using a $\mathrm{p}^{\mathrm{H}}$ meter, to ensure they were within tolerable limits.

\section{Survival and Mortality:}

Survival and mortality of fish in each treatment were monitored by counting the mortalities on a daily basis.

\section{Statistical Analysis:}

The data collected was subjected to analysis using one-way analysis of variance (ANOVA) and Duncan's Multiple Range Test (DMRT) was used to compare the means.

\section{RESULTS AND DISCUSSION}

Measurements of weight and length were carried out weekly to determine increase in growth. The data obtained was also used to determine the following parameters MW, WG, SGR and K. These are presented in Table 1.

Maximum weight of $7.39 \pm 0.19 \mathrm{~g}$ was recorded in Treatment 3 and a minimum of $5.35 \pm 0.31 \mathrm{~g}$ was obtained in Treatment 1 . In terms of SGR (\%), Treatment 3 had the highest value of $1.19 \pm 0.02 \mathrm{~g}$ and the lowest $1.01 \pm 0.03 \mathrm{~g}$ was recorded in Treatment 1.Mean weight gain is presented in table 2. Treatment 3 favored higher weight gain of $9.09 \pm 2.68 \mathrm{~g}$.

Highest feed conversion ratio of $1.88 \pm 1.37$ was also recorded in Treatment 3 while the minimum value of $8.34 \pm 2.12$ was obtained in Treatment 1 .

The least fish growth indices (WG and SGR) and highest FCR were recorded in Treatment 3, while highest values of growth indices and lowest FCR were obtained in Treatment 3; as such T3 gave the best performance in terms of growth and feed utilization.

Table 1: Growth parameters of the experimental fish (Clarias gariepinus) fed at varying frequencies.

\begin{tabular}{llll}
\hline Parameters & \multicolumn{1}{c}{ T1 } & \multicolumn{1}{c}{ T2 } & T3 \\
\hline IMW $(\mathrm{g})$ & $2.41 \pm 0.21$ & $2.39 \pm 0.15$ & $2.37 \pm 0.18$ \\
FMW $(\mathrm{g})$ & $10.05 \pm 1.11^{\mathrm{d}}$ & $11.05 \pm 1.32^{\mathrm{b}}$ & $11.32 \pm 1.40^{\mathrm{a}}$ \\
WG $(\mathrm{g})$ & $5.35 \pm 0.31^{\mathrm{d}}$ & $6.27 \pm 0.28^{\mathrm{c}}$ & $7.39 \pm 0.19^{\mathrm{a}}$ \\
SGR $(\%)$ & $1.01 \pm 0.03^{\mathrm{d}}$ & $1.10 \pm 0.05^{\mathrm{c}}$ & $1.19 \pm 0.02^{\mathrm{a}}$ \\
FCR & $8.34 \pm 2.12^{\mathrm{d}}$ & $5.65 \pm 1.19^{\mathrm{c}}$ & $1.88 \pm 1.37^{\mathrm{a}}$ \\
K & $0.59 \pm 0.09^{\mathrm{d}}$ & $0.73 \pm 0.03^{\mathrm{bc}}$ & $0.84 \pm 0.02^{\mathrm{a}}$ \\
\hline
\end{tabular}

Where: IMW = Initial Mean Weight, FMW = Final Mean Weight, MWG = Mean Weight Gain, WG = Weight Gain, $\mathrm{SGR}=$ Specific Growth Rate, FCR = Food Conversion Ratio, $\mathrm{K}=$ Condition Factor and $\mathrm{SR}=$ Survival Rate respectively

*Means in row with same letter are not significantly different $(p>0.05)$

Studies conducted on other fish species have shown that feed consumption and growth generally increased with feeding frequency up to a given limit, (Wang et al., 1998; Bascinar et al., 2007). This is in line with the findings in this study that feeding frequency had a significant effect on feed consumption and growth. T3 gave the best result in terms of feed conversion ratio (FCR) and other growth indices. This indicates that both growth and feed utilization were most efficient at this feeding frequency.

\section{CONCLUSION}

Increased feed digestibility and increased water quality are the benefits of using the correct feeding frequency. The result of this work is also in agreement with the findings of Ruohonen et al., (1998); that two or three times feeding a day is sufficient for maximum growth of a number of different fish species. This supports the hypothesis that more frequent feeding yields fish of more uniform sizes and this could arise because dominant individuals are less aggressive under such circumstances, or because more food is distributed to locations occupied by subordinates (Bascinar et al., 2007). The inter-individual size variation of fish in Treatment 3 was also lower than in the other Treatments. The study revealed that (T3) four times per day feeding frequency had the best growth performance for the culture of Clarias gariepinus. 


\section{REFERENCES}

Agung, N. (2004): Comparism of Lupin meal based diets cost efficiency for juvenile, Penaeus monodon tested under pond conditions. J. Coastal Dev., 8(1): 47-51.

Bascinar N., Cakmak E., Cavdar Y. and Aksungur N. (2007): The effect of feeding frequency on growth performance and feed conversion rate of Black sea trout (Salmo trutta labrax Pallas, 1811). Tur J. Fisheries Aqua. Sci. 7:13-17.

Charles P.M., Sebastian S. Raj M.C.V., Marian M.P. (1984): Effect of feeding frequency on growth and feed conversion, Cyprinus carpio fry. Aquacult., 40:293-300.

Davies, O.A., Inko-Tariah M.B., and Amachree, D. (2006): Growth response and survival of Heterobronchus longifilis Fingerlings fed at different feeding frequencies. Afr. $J$. Biotechnol., 5:778-787.

Goddard, S. (1995): Feed Management in Intensive Aquaculture, Chapman and Hall, New York. $194 p$
Gokcek, C.K., Mazlum Y., and Akyurt, I. (2008): Effects of feeding frequency on the growth and survival of Himri barbell and Barbus luteus fry under laboratory conditions. Pak. J. Nutr., 7(1): 66-69.

Jobling, M. (1995): Fish Bioenergetics, Chapman and Hall, London, 309p

Ruohonen, K., Vielma J., and Grove, D..J. (1998): Effects of feeding frequency on growth and food Utilization of Rainbow trout Oncorhynchus mykiss fed low-fat Herring or dry pellets. Aquacult. 165:111-121.

Sogbesan, A.O., and Ugwumba A.A.A. (2008): Nutritional evaluation of termite Macroptermes subhyalinus meal as animal protein supplements in the diets of Heterobronchus longifilis fingerlings, Tur. J. fisheries and aquatic sci., 8:149-157.

Wang, N., Heyward, R.S, and Noltie D.B. (1998): Effect of feeding frequency on food consumption, growth, size variation and feeding pattern of Age-0 hybrid Sunfish. Aquacult., 165:261-267. 